\title{
Unilateral acute anterior uveitis is associated with ipsilateral changes in the tear fluid proteome that involves the LXR/ RXR pathway
}

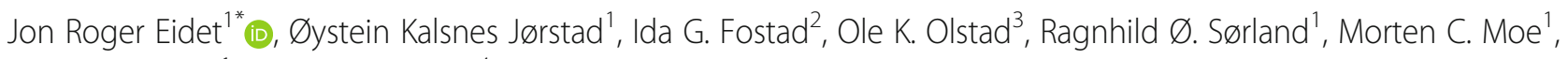
Goran Petrovski ${ }^{1}$ and Milaim Pepaj ${ }^{4}$

\begin{abstract}
Purpose: To determine whether unilateral acute anterior uveitis (AAU) induces ipsilateral changes in the tear fluid proteome.

Methods: Five patients (25-77 years old) with unilateral AAU were included. Tear fluid samples were obtained using Schirmer's test strips. The healthy eye served as control. Proteins were identified by liquid chromatography tandem mass spectrometry.

Results: Two hundred forty-two tear fluid sample proteins were identified, of which 75 were present in at least three patients. Nine proteins were at least 1.5-fold increased, whereas eight were at least 1.5 -fold decreased in tears from the diseased eye compared with the healthy eye. APOBEC3A was significantly increased (1.43-fold; $P=0.04)$, whereas TGM2 was significantly decreased $(-1.21$-fold; $P=0.03)$ in tears from the diseased eye relative to the healthy eye. Ingenuity Pathway Analysis identified LXR/RXR $(P<1.02 \mathrm{E}-4)$ as a top canonical pathway.
\end{abstract}

Conclusion: Unilateral AAU induced detectable changes in the ipsilateral tear fluid proteome and involvement of the inflammation-associated LXR/RXR pathway.

Keywords: Uveitis, Tear fluid, Proteomics

\section{Introduction}

Uveitis denotes a heterogeneous group of diseases characterized by intraocular inflammation. Among the uveitis subtypes, inflammation most commonly involves the eye's anterior segment (30-60\% of all uveitis cases) [1]. Acute anterior uveitis (AAU) is usually unilateral in its presentation. AAU typically resolves following prompt and adequate ophthalmic care. A delayed diagnosis, however, is associated with an increased risk of potentially severe complications [2, 3]. The diagnosis of AAU

\footnotetext{
* Correspondence: j.r.eidet@gmail.com

${ }^{1}$ Center for Eye Research, Department of Ophthalmology, Oslo University Hospital, University of Oslo, Oslo, Norway

Full list of author information is available at the end of the article
}

typically requires ophthalmic work-up and is aided by slit-lamp examination. On the other hand, nonophthalmologist doctors may easily misinterpret AAU as harmless external eye disease, e.g., common infectious conjunctivitis. As a consequence of a false diagnosis, adequate treatment may be delayed. Nevertheless, patients are often primarily admitted to general practitioners lacking access to slit-lamps and other ophthalmic instruments. Consequently, there is a need for a simple diagnostic method to diagnose AAU, thereby preventing delays in diagnosis, treatment, and subsequent complications.

Blood tests to detect inflammation are diagnostic cornerstones in a vast number of medical conditions. In

\section{Springer Open}

(อ) The Author(s). 2020 Open Access This article is licensed under a Creative Commons Attribution 4.0 International License, which permits use, sharing, adaptation, distribution and reproduction in any medium or format, as long as you give appropriate credit to the original author(s) and the source, provide a link to the Creative Commons licence, and indicate if changes were made. The images or other third party material in this article are included in the article's Creative Commons licence, unless indicated otherwise in a credit line to the material. If material is not included in the article's Creative Commons licence and your intended use is not permitted by statutory regulation or exceeds the permitted use, you will need to obtain permission directly from the copyright holder. To view a copy of this licence, visit http://creativecommons.org/licenses/by/4.0/. 
AAU, however, blood analyses lack necessary sensitivity and specificity. On the other hand, diagnostic samples from the eye's aqueous humor or vitreous body necessitate invasive techniques that pose a risk of serious ocular complications. By contrast, tear fluid sampling is noninvasive, harmless, and easily performed with minimal training. Moreover, elevated cytokine levels have been demonstrated in tear fluid of AAU patients [3]. Accordingly, there is a rationale for investigating the diagnostic potential of tear fluid biomarkers in AAU.

By virtue of advancing proteomic analysis methods, quantification of more than 1.500 tear fluid proteins can potentially be achieved [4]. Furthermore, in unilateral AAU, tear fluid samples from the healthy eye can serve as control and allow for validation of AAU-associated proteins. The basis for examining tear fluid proteins has been laid in studies of disorders like rosacea, dry eye syndromes, and Graves' disease [5]. The tear fluid proteome in AAU is less explored, but some data do exist. First, one study assessed tear fluid cytokines and chemokines in uveitis patients [3]. It did not examine the full tear fluid proteome but instead used a multiplex bead analysis that assayed 21 predefined molecules. The authors concluded there were significant differences in the levels of several cytokine in uveitis patients compared with healthy controls. Secondly, in a conference abstract, Angeles-Han et al. reported results from a pilot study on proteome analysis of tear fluid obtained with Schirmer's strips from children with idiopathic or juvenile idiopathic arthritis (JIA)-associated anterior uveitis [6]. The investigation detected 1.224 unique protein groups, of which 120 were significantly different from healthy controls. Finally, in a study on tear proteome by Chunky et al., lactoferrin and lipocalin were identified as promising biomarkers for JIA-associated uveitis [7]. Nevertheless, there are no well-defined tear fluid biomarkers for AAU, let alone a consensus about their diagnostic value.

To assess the potential use of tear fluid for diagnostic purposes in AAU, the current pilot study aimed at exploring whether unilateral AAU is associated with ipsilateral changes in the tear fluid proteome.

\section{Materials and methods}

\section{Patients}

The study included five adult patients diagnosed with unilateral AAU at the Department of Ophthalmology at Oslo University Hospital, Norway. All patients were examined by the same ophthalmologist, and the AAU diagnosis was based on (1) Findings: unilateral anterior chamber cells (obligate) and ipsilateral anterior chamber flare, ciliary injection, and miosis. (2) Symptoms: ocular pain and photophobia. Exclusion criteria were age $<18$ years, pregnancy, bilateral AAU, intermediate-, posterior- or pan-uveitis, AAU secondary to suspected or known infectious disease, presence of any concurrent ocular disease (including dry eye syndrome, conjunctivitis, keratitis, eyelid disease, glaucoma, or neoplastic disease), prior severe ocular trauma, prior ocular surgery, intraocular pressure $<6$ or $>21 \mathrm{mmHg}$, use of topical eye medication, use of systemic anti-inflammatory medication, or smoking.

\section{Tear fluid sampling}

The research group used a modified version of a previously described protocol for utilizing Schirmer's strips to examine tear fluid proteins $[4,5]$. In brief, one Schirmer's test strip was placed in each eye's inferior fornix without concurrent anesthesia and left for $5 \mathrm{~min}$ with eyes closed. The strips were then immediately transferred to microcentrifuge tubes and stored at $-140{ }^{\circ} \mathrm{C}$ until analyses. To detect changes in the tear fluid proteome of the AAU eye, the healthy eye served as control.

\section{Protein extraction}

Protein extraction was performed according to a protocol previously reported by the research group $[4,5]$.

\section{Ingenuity Pathway Analysis}

To explore biological function, lists of protein identifiers (UniProt) were uploaded onto the web-delivered application Ingenuity Pathways Analysis (IPA) (QIAGEN N.V., Venlo, Netherlands).

\section{Statistical analysis}

The R statistical software (R Development Core Team, R 3.4.2 GUI 1.70 El Capitan build [7434]) was used for statistical analyses; a one-sample $t$ test was used to compare the AAU eyes with the respective healthy controls.

\section{Results}

Patients

The patients' clinical data are presented in Table 1.

\section{Relative tear fluid protein levels in the diseased eye versus the healthy eye}

Relative protein ratios were calculated for 242 tear fluid proteins present in both the diseased and the healthy eye. Of these nine were at least 1.5-fold increased, and eight were at least 1.5 -fold decreased in the diseased eye compared with the healthy control. Apolipoprotein $\mathrm{B}$ mRNA editing enzyme catalytic subunit 3A (APOBEC3A) was significantly increased in the diseased eye compared with the healthy control (fold change 1.43; $P$ $=0.04$ ), whereas transglutaminase 2 (TGM2) was significantly decreased in the diseased eye compared with the healthy control (fold change $-1.21 ; P=0.03$ ). Table 2 summarizes the relative ratios of the top 20 upregulated proteins for each of the five patients. 
Table 1 Patients with unilateral acute anterior uveitis included in the study

\begin{tabular}{|c|c|c|c|c|c|}
\hline & Patient 1 & Patient 2 & Patient 3 & Patient 4 & Patient 5 \\
\hline Age (years) & 28 & 57 & 41 & 25 & 77 \\
\hline Sex & Male & Male & Female & Male & Female \\
\hline Ethnicity & Caucasian & Caucasian & Caucasian & Caucasian & Caucasian \\
\hline HLA-B27 status & Unknown & $\begin{array}{l}\text { HLA-B27 } \\
\text { negative }\end{array}$ & $\begin{array}{l}\text { HLA-B27 positive and palmoplantar } \\
\text { psoriasis }\end{array}$ & Unknown & $\begin{array}{l}\text { HLA-B27 } \\
\text { positive }\end{array}$ \\
\hline Previous episodes of AAU & No & No & No & Yes & No \\
\hline $\begin{array}{l}\text { Duration of symptoms prior to tear fluid sampling } \\
\text { (days) }\end{array}$ & 1 & 10 & 5 & 1 & 7 \\
\hline AC flare (laser flare photometry) & $47 / 4$ & $3 / 54$ & $129 / 3$ & $11 / 3$ & * \\
\hline AC flare (Sun criteria) & $\S$ & $0 /+2$ & $+2 / 0$ & $+1 / 0$ & $+4 / 0$ \\
\hline AC cells (Sun criteria) & $\S$ & $0 /+1$ & $+1 / 0$ & $\pm / 0$ & $+4 / 0$ \\
\hline Corneal precipitates & $\S$ & Non-granular & Non-granular & None & Non-granular \\
\hline AC fibrin & No & No & No & No & Yes \\
\hline AC hypopyon & No & No & No & No & No \\
\hline Posterior synechiae & No & No & No & No & Yes \\
\hline Cells in anterior vitreous & No & No & No & No & $\#$ \\
\hline Decimal visual acuity & $1.0 / 1.0$ & 1.0/1.0-- & $1.2++/ 1.5--$ & $\begin{array}{l}1.2++1 \\
1.2++\end{array}$ & CF/1.0-- \\
\hline Intraocular pressure $(\mathrm{mmHg})$ & $14 / 17$ & $13 / 7$ & $10 / 14$ & $7 / 10$ & $20 / 10$ \\
\hline Schirmer test type $1(0-40 ; \mathrm{mm})$ & $40 / 40$ & $33 / 40$ & $17 / 7$ & $7 / 7$ & $30 / 10$ \\
\hline
\end{tabular}

Bilateral measurements are presented as right eye/left eye

$A A U$ acute anterior uveitis, $A C$ anterior chamber, $C F$ counting fingers

${ }^{*}$ Measurement not obtained

$\S$ The standardization of uveitis nomenclature criteria not reported

\# Posterior segment not visible

Thirty-two tear fluid proteins were identified in all five patients; the number of matching proteins was highest between patients 1, 3, and 4 (Fig. 1).

\section{Ingenuity Pathway Analysis}

For all patients, IPA identified the liver $\mathrm{X}$ receptor/retinoid $\mathrm{X}$ receptor (LXR/RXR) and the farnesoid X receptor/retinoid X receptor (FXR/RXR) among the "Top Canonical Pathways" affected in the tear fluid (Table 3).

Upstream regulator analysis in IPA aims to identify transcriptional regulators that can explain the observed changes in the dataset. IPA identified interleukin 6 (IL6) and/or tumor necrosis factor (TNF) as possible upstream regulators in four of the five patients (Table 4).

Furthermore, for all patients IPA recognized "inflammatory response" and "immune cell trafficking" among the top categories within "Diseases and Bio functions" (Tables 5 and 6).

\section{Discussion}

The current pilot study identifies ipsilateral changes in the tear fluid proteome of patients with unilateral AAU. Accordingly, Schirmer's test sampling of tear fluid potentially represents an adjuvant non-invasive approach to investigate the pathophysiological pathways in AAU.
For all patients, IPA identified the LXR/RXR and FXR/ RXR pathways among the top canonical pathways affected. LXRs have predominantly been linked to regulation of lipid metabolism, but there is also mounting evidence of an anti-inflammatory role [9]. LXRs modulate the immune response in lipopolysaccharideactivated macrophages by inhibiting expression of inflammatory mediators, including IL6 [10]. LXR activation has also been associated with inhibition of the nuclear transcription factor- $\mathrm{kB}$ (NF- $\mathrm{kB})$ [11], which is a major transcription factor in the regulation of immune responses. In rats, inhibition of NF- $\mathrm{kB}$ ameliorated anterior uveitis in experimental autoimmune uveitis (EAU) [12]. Furthermore, in a mouse model of EAU, a synthetic LXR agonist reduced ocular inflammation [13]. The authors of the latter study suggested that LXR agonists had potential for becoming a therapeutic option for uveitis patients. LXRs were expressed in the native rat corneal epithelium and stroma in a rat model of inflammatory corneal angiogenesis [14]. Following induction of inflammatory corneal angiogenesis, LXR expression temporarily decreased in the corneal epithelium, while removal of the inflammatory stimulus (corneal suture) was associated with activation of the LXR/RXR pathway and resolution of inflammation. Consequently, the authors 
Table 2 Top 20 upregulated protein level ratios found in tear fluid of the diseased eye relative to the healthy eye of patients with unilateral acute anterior uveitis

\begin{tabular}{|c|c|c|c|c|c|c|c|c|c|}
\hline Patient 1 & & Patient 2 & & Patient 3 & & Patient 4 & & Patient 5 & \\
\hline Protein symbol & $R R$ & Protein symbol & $R R$ & Protein symbol & $R R$ & Protein symbol & $R R$ & Protein symbol & $R R$ \\
\hline SERPINA3 & 14.73 & ZG16B & 5.62 & DGKZ & 9.13 & KRT32 & 8.96 & FGB & 5.33 \\
\hline CEP104 & 4.32 & GAPDH & 3.17 & SCGB2A1 & 6.19 & PTCHD1 & 2.70 & $\mathrm{APOH}$ & 4.87 \\
\hline RARRES1 & 3.29 & LTF & 2.89 & PLA2G2A & 6.04 & EEF1A1 & 2.55 & OPRPN & 3.85 \\
\hline ALDH3A1 & 2.85 & DCD & 2.86 & SCGB1D1 & 4.19 & TPI1 & 2.33 & $\mathrm{~A} 2 \mathrm{M}$ & 3.79 \\
\hline ADIRF & 2.68 & OPRPN & 2.70 & WWC3 & 3.64 & ADIRF & 1.96 & $\mathrm{C} 4 \mathrm{~A} / \mathrm{C} 4 \mathrm{~B}$ & 2.57 \\
\hline KRT10 & 2.59 & S100P & 2.46 & LYZ & 3.58 & S100A11 & 1.95 & WWC3 & 2.49 \\
\hline CST1 & 2.46 & GSN & 2.12 & OPRPN & 3.35 & GSTP1 & 1.91 & HPR & 2.33 \\
\hline FABP5 & 2.20 & SCGB1D1 & 1.98 & PSME2 & 2.65 & SCGB1D1 & 1.88 & C3 & 2.17 \\
\hline $\mathrm{ADH7}$ & 2.19 & EEF1A1 & 1.88 & CST1 & 2.54 & ANXA2 & 1.83 & APOA1 & 2.05 \\
\hline CP & 2.06 & AZGP1 & 1.82 & LACRT & 2.35 & LDHA & 1.68 & ORM2 & 2.00 \\
\hline TMSB10/TMSB4X & 1.76 & TXN & 1.80 & MASP1 & 2.27 & ILIRN & 1.64 & $\mathrm{~A} 1 \mathrm{BG}$ & 1.81 \\
\hline IL1RN & 1.75 & PIP & 1.79 & B2M & 2.03 & GPI & 1.62 & HPX & 1.62 \\
\hline RPLP1 & 1.70 & WWC3 & 1.69 & $\mathrm{~A} 1 \mathrm{BG}$ & 1.91 & PSME2 & 1.62 & TF & 1.50 \\
\hline SFN & 1.70 & LCN1 & 1.52 & LCN1 & 1.76 & IGHG2 & 1.60 & PIP & 1.48 \\
\hline SH3BGRL & 1.63 & LYZ & 1.43 & LTF & 1.75 & APOBEC $3 \mathrm{~A}$ & 1.59 & CLU & 1.45 \\
\hline WFDC2 & 1.57 & ALB & 1.22 & S100A6 & 1.73 & B2M & 1.58 & DMBT1 & 1.44 \\
\hline CTIF & 1.55 & C3 & 1.16 & HPX & 1.71 & FGG & 1.58 & CST1 & 1.40 \\
\hline DBI & 1.53 & PKM & 1.14 & CST4 & 1.67 & CFL1 & 1.53 & SERPINA3 & 1.34 \\
\hline YWHAE & 1.50 & ACTB & 1.13 & LGALS3 & 1.67 & SERPINB1 & 1.50 & IGHG2 & 1.33 \\
\hline ACTN4 & 1.49 & CLU & 1.12 & PIP & 1.66 & ATG9A & 1.50 & PFN1 & 1.25 \\
\hline
\end{tabular}

$R R$ relative ratio of protein level in tear fluid of diseased versus healthy eye

suggested that LXR/RXR pathway activation could contribute to resolution of corneal inflammation. To our knowledge, the FXR/RXR pathway has not been directly linked to the pathogenesis of uveitis. In a study on endotoxin-induced uveitis in rats, however, the FXR antagonist guggulsterone suppressed ocular inflammation [15]. The authors related this effect to the inhibition of $\mathrm{NF}-\mathrm{kB}$ by guggulsterone. Ultimately, engagement of the LXR/RXR and FXR/RXR pathways in the current study indicates that signs of AAU-associated inflammation are detectable in ipsilateral tear fluid samples.

In the current study, IPA determined that the changes to the tear proteome in AAU were associated with an inflammatory process (i.e., inflammatory response and immune cell trafficking were among the top diseases and bio functions). The upstream analysis by IPA further underscored the inflammatory tear profile by identifying TNF and IL6 among the top upstream regulators in four of the five patients. The role of TNF in the pathogenesis of uveitis has been wellestablished in animal studies [16, 17], and the concentration of TNF was also raised in the aqueous humor of patients with uveitis [18]. Most importantly, the essential role of TNF in uveitis has been confirmed by the recent success of employing the TNF-inhibitor adalimumab in the treatment of noninfectious uveitis $[19,20]$. IL6 promotes the differentiation of CD4+ T-helper (Th) cells into Th17 cells, thereby contributing to the pathogenesis of autoimmune diseases [21]. In uveitis, IL6 has been proposed to be especially important in HLA-B27 positive cases [22]. The latter study also reported a higher concentration of IL6 in the aqueous humor of HLAB27 positive uveitis patients compared to patients with Vogt-Koyanagi-Harada disease, sarcoidosis, or idiopathic granulomatous uveitis. This is in line with our study, in which IPA identified IL6 as an upstream regulator in the two HLA-B27 positive patients.

We found a significantly higher level of APOBEC3A, a DNA cytidine deaminase, in tear fluid of the diseased eye relative to the healthy control. Interferon, a regulating cytokine in autoimmune uveitis [23], can induce APOBEC3A in monocytes. This enables deamination of foreign double-stranded DNA and inhibits replication of retroviruses and retrotransposons [24]. In this way, APOBEC3A partakes in the innate immune system, and its increase in tear fluid from AAU eyes indicates local disease activity. 


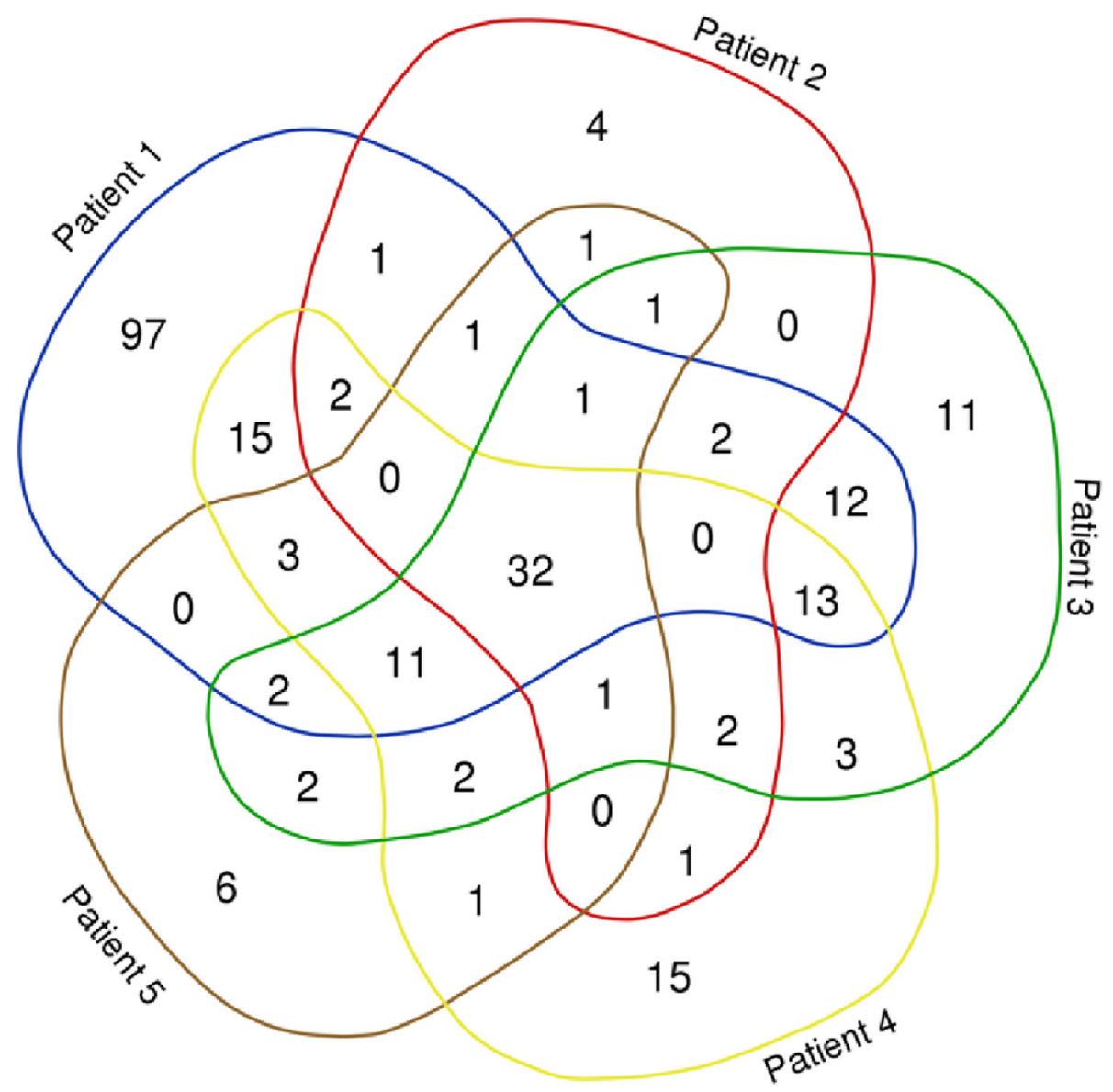

Fig. 1 Venn diagram illustrating the number and distribution of matching tear fluid proteins in five patients with acute anterior uveitis [8]

The level of TGM2 was reduced in tear fluid from the diseased eye. This is contradictory to a study on endotoxin-induced uveitis, in which the level of TGM2 was increased in aqueous humor [25]. In agreement with our results, however, studies on Crohn's disease patients have reported an inverse relationship between TGM2 and disease activity [26].

In total, 242 unique proteins were identified in the tear fluid samples. Only 32 proteins, however, were identified in all patients. The highest number of matching tear fluid proteins was seen in the three youngest patients

Table 3 Top canonical pathways

\begin{tabular}{|c|c|c|c|c|c|c|c|c|c|}
\hline Patient 1 & & Patient 2 & & Patient 3 & & Patient 4 & & Patient 5 & \\
\hline Protein & $\begin{array}{l}P \\
\text { value }\end{array}$ & Protein & $\begin{array}{l}P \\
\text { value }\end{array}$ & Protein & $\begin{array}{l}P \\
\text { value }\end{array}$ & Protein & $\begin{array}{l}P \\
\text { value }\end{array}$ & Protein & $\begin{array}{l}P \\
\text { value }\end{array}$ \\
\hline $\begin{array}{l}\text { LXR/RXR } \\
\text { activation }\end{array}$ & $\begin{array}{l}2.04 \mathrm{E} \\
-12\end{array}$ & Glycolysis I & $\begin{array}{l}2.06 \mathrm{E} \\
-07\end{array}$ & LXR/RXR activation & $\begin{array}{l}3.14 \mathrm{E} \\
-15\end{array}$ & $\begin{array}{l}\mathrm{LXR} / \mathrm{RXR} \\
\text { activation }\end{array}$ & $\begin{array}{l}3.11 \mathrm{E} \\
-18\end{array}$ & LXR/RXR activation & $\begin{array}{l}2.92 \mathrm{E} \\
-19\end{array}$ \\
\hline Glycolysis I & $\begin{array}{l}3.13 \mathrm{E} \\
-11\end{array}$ & LXR/RXR activation & $\begin{array}{l}1.02 \mathrm{E} \\
-04\end{array}$ & FXR/RXR activation & $\begin{array}{l}1.69 \mathrm{E} \\
-13\end{array}$ & $\begin{array}{l}\text { Acute phase } \\
\text { response } \\
\text { signaling }\end{array}$ & $\begin{array}{l}5.67 E \\
-16\end{array}$ & FXR/RXR activation & $\begin{array}{l}2.88 \mathrm{E} \\
-17\end{array}$ \\
\hline $\begin{array}{l}\text { FXR/RXR } \\
\text { activation }\end{array}$ & $\begin{array}{l}8.01 \mathrm{E} \\
-10\end{array}$ & $\begin{array}{l}\text { Clathrin-mediated } \\
\text { endocytosis signaling }\end{array}$ & $\begin{array}{l}6.79 E \\
-04\end{array}$ & $\begin{array}{l}\text { Acute phase response } \\
\text { signaling }\end{array}$ & $\begin{array}{l}2.32 \mathrm{E} \\
-09\end{array}$ & $\begin{array}{l}\text { FXR/RXR } \\
\text { activation }\end{array}$ & $\begin{array}{l}7.25 \mathrm{E} \\
-15\end{array}$ & $\begin{array}{l}\text { Acute phase response } \\
\text { signaling }\end{array}$ & $\begin{array}{l}1.53 \mathrm{E} \\
-15\end{array}$ \\
\hline Gluconeogenesis I & $\begin{array}{l}1.61 \mathrm{E} \\
-09\end{array}$ & Gluconeogenesis I & $\begin{array}{l}1.25 E \\
-03\end{array}$ & $\begin{array}{l}\text { Atherosclerosis } \\
\text { signaling }\end{array}$ & $\begin{array}{l}2.97 E \\
-09\end{array}$ & Glycolysis I & $\begin{array}{l}1.24 \mathrm{E} \\
-11\end{array}$ & $\begin{array}{l}\text { Clathrin-mediated } \\
\text { endocytosis signaling }\end{array}$ & $\begin{array}{l}5.04 \mathrm{E} \\
-09\end{array}$ \\
\hline $\begin{array}{l}\text { Acute phase } \\
\text { response } \\
\text { signaling }\end{array}$ & $\begin{array}{l}2.36 \mathrm{E} \\
-09\end{array}$ & FXR/RXR activation & $\begin{array}{l}2.08 \mathrm{E} \\
-03\end{array}$ & $\begin{array}{l}\text { Clathrin-mediated } \\
\text { endocytosis signaling }\end{array}$ & $\begin{array}{l}1.06 \mathrm{E} \\
-08\end{array}$ & $\begin{array}{l}\text { Atherosclerosis } \\
\text { signaling }\end{array}$ & $\begin{array}{l}3.63 \mathrm{E} \\
-09\end{array}$ & Glycolysis I & $\begin{array}{l}1.01 \mathrm{E} \\
-08\end{array}$ \\
\hline
\end{tabular}


Table 4 Top upstream regulators

\begin{tabular}{|c|c|c|c|c|c|c|c|c|c|}
\hline \multicolumn{2}{|c|}{ Patient 1} & \multicolumn{2}{|l|}{ Patient 2} & \multicolumn{2}{|c|}{ Patient 3} & \multicolumn{2}{|l|}{ Patient 4} & \multicolumn{2}{|l|}{ Patient 5} \\
\hline Protein & $P$ value & Protein & $P$ value & Protein & $P$ value & Protein & $P$ value & Protein & $P$ value \\
\hline MAPT & $1.32 \mathrm{E}-24$ & APP & $5.03 E-11$ & MAPT & 7.78E-15 & IL6 & $1.65 E-16$ & MAPT & $5.83 \mathrm{E}-12$ \\
\hline APP & $1.78 \mathrm{E}-22$ & MAPT & $5.49 \mathrm{E}-11$ & APP & $6.79 E-13$ & APP & $1.46 \mathrm{E}-14$ & APP & $1.72 \mathrm{E}-11$ \\
\hline TP53 & $3.21 \mathrm{E}-19$ & PSEN1 & 2.71E-09 & TNF & $8.03 \mathrm{E}-13$ & MAPT & $2.12 \mathrm{E}-13$ & ZNF106 & $3.96 \mathrm{E}-11$ \\
\hline TNF & $9.00 E-19$ & Growth hormone & 2.87E-07 & PSEN1 & $3.75 E-12$ & PCGEM1 & $4.90 \mathrm{E}-12$ & PSEN1 & $6.04 \mathrm{E}-10$ \\
\hline PSEN1 & $1.40 \mathrm{E}-17$ & MYC & $7.50 \mathrm{E}-07$ & IL6 & $1.04 \mathrm{E}-11$ & TNF & $5.37 \mathrm{E}-11$ & IL6 & $9.72 \mathrm{E}-1 \mathrm{C}$ \\
\hline
\end{tabular}

that also had the shortest disease duration. On the other hand, HLA-B27 status was not obviously related to the number of matching tear fluid proteins. Nevertheless, as the anterior chamber cytokine profile differs between HLA-B27 positive and negative patients, the heterogeneity in HLA-B27 status might have contributed to the relative lack of matching proteins between patients in the current study.

In our study, tear fluid proteins were identified using a single Schirmer's test strip in each patient. Previous studies have reported a higher number of identified proteins when pooling tear fluid samples from multiple patients [5]. Although proteomics is useful as a screening method for AAU biomarkers, the method has limited sensitivity for low-concentration proteins. Alternative methods, including enzyme-linked immunosorbent assay, are more suitable for detecting proteins at low concentrations. Accordingly, restricted sensitivity may have contributed to the rather poor correspondence of tear fluid proteins between the patients in the current study. Conclusively, we believe that failure to identify certain proteins across all patients in the present study should not lead to the exclusion of these as potential biomarkers.
Serpent family A member 3 (SERPINA3), also known as serine protease inhibitor 3 (SPI-3), was more than 14fold elevated in tear fluid from the diseased eye in one patient, despite disease duration of only a single day. In addition, this protein was mildly elevated in two other patients. SERPINA3, also referred to as SPI-3, is normally found in the aqueous humor [27], but it is also part of the acute phase response. In endotoxin-induced uveitis in rats following lipopolysaccharide injection, SERPINA3 mRNA in epithelial cells of the iris and ciliary body was rapidly upregulated as part of the initial inflammatory response [28]. Yet another potential biomarker protein was increased in tear fluid from the diseased eye in three patients: orosomucoid 2 (ORM2), also known as alpha-1-acid glycoprotein. Similar to SERPINA3, ORM2 is an acute phase response protein. In a previous study, serum levels of ORM2 were increased in moderate and severe idiopathic AAU [29]. Furthermore, in the latter study, ORM2 levels correlated with disease severity and returned to normal following resolution.

In conclusion, unilateral AAU induces inflammationassociated changes in the ipsilateral tear fluid proteome; in a clinical setting, Schirmer's strips can be used to collect tear samples for proteomics. The inflammation-

Table 5 Top diseases and bio functions-diseases and disorders

\begin{tabular}{|c|c|c|c|c|c|c|c|c|c|}
\hline \multicolumn{2}{|l|}{ Patient 1} & \multicolumn{2}{|l|}{ Patient 2} & \multicolumn{2}{|l|}{ Patient 3} & \multicolumn{2}{|l|}{ Patient 4} & \multicolumn{2}{|l|}{ Patient 5} \\
\hline Protein & $P$ value & Protein & $P$ value & Protein & $P$ value & Protein & $P$ value & Protein & $P$ value \\
\hline $\begin{array}{l}\text { Dermatological } \\
\text { diseases and } \\
\text { conditions }\end{array}$ & $\begin{array}{l}1.25 \mathrm{E}-04 \\
\text { to } 3.17 \mathrm{E} \\
-25\end{array}$ & $\begin{array}{l}\text { Inflammatory } \\
\text { response }\end{array}$ & $\begin{array}{l}4.02 \mathrm{E}-03 \\
\text { to } 1.91 \mathrm{E} \\
-10\end{array}$ & $\begin{array}{l}\text { Inflammatory } \\
\text { response }\end{array}$ & $\begin{array}{l}3.49 \mathrm{E}-04 \\
\text { to } 9.03 \mathrm{E} \\
-20\end{array}$ & $\begin{array}{l}\text { Metabolic } \\
\text { disease }\end{array}$ & $\begin{array}{l}2.52 \mathrm{E}-04 \\
\text { to } 1.54 \mathrm{E} \\
-16\end{array}$ & $\begin{array}{l}\text { Metabolic } \\
\text { disease }\end{array}$ & $\begin{array}{l}2.69 \mathrm{E}-03 \\
\text { to } 1.27 \mathrm{E} \\
-14\end{array}$ \\
\hline $\begin{array}{l}\text { Organismal injury } \\
\text { and abnormalities }\end{array}$ & $\begin{array}{l}2.03 \mathrm{E}-04 \\
\text { to } 3.17 \mathrm{E} \\
-25\end{array}$ & $\begin{array}{l}\text { Organismal } \\
\text { injury and } \\
\text { abnormalities }\end{array}$ & $\begin{array}{l}4.02 \mathrm{E}-03 \\
\text { to } 1.91 \mathrm{E} \\
-10\end{array}$ & $\begin{array}{l}\text { Organismal } \\
\text { injury and } \\
\text { abnormalities }\end{array}$ & $\begin{array}{l}3.49 \mathrm{E}-04 \\
\text { to } 9.03 \mathrm{E} \\
-20\end{array}$ & $\begin{array}{l}\text { Connective } \\
\text { tissue disorders }\end{array}$ & $\begin{array}{l}3.72 \mathrm{E}-04 \\
\text { to } 6.67 \mathrm{E} \\
-16\end{array}$ & $\begin{array}{l}\text { Inflammatory } \\
\text { response }\end{array}$ & $\begin{array}{l}2.55 \mathrm{E}-03 \\
\text { to } 2.94 \mathrm{E} \\
-14\end{array}$ \\
\hline Metabolic disease & $\begin{array}{l}1.89 E-04 \\
\text { to } 3.65 E \\
-23\end{array}$ & $\begin{array}{l}\text { Hematological } \\
\text { disease }\end{array}$ & $\begin{array}{l}3.44 E-03 \\
\text { to } 3.53 E \\
-10\end{array}$ & $\begin{array}{l}\text { Metabolic } \\
\text { disease }\end{array}$ & $\begin{array}{l}3.18 \mathrm{E}-04 \\
\text { to } 7.41 \mathrm{E} \\
-18\end{array}$ & $\begin{array}{l}\text { Inflammatory } \\
\text { disease }\end{array}$ & $\begin{array}{l}5.16 \mathrm{E}-04 \\
\text { to } 6.67 \mathrm{E} \\
-16\end{array}$ & $\begin{array}{l}\text { Hematological } \\
\text { disease }\end{array}$ & $\begin{array}{l}2.32 \mathrm{E}-03 \\
\text { to } 2.21 \mathrm{E} \\
-13\end{array}$ \\
\hline $\begin{array}{l}\text { Inflammatory } \\
\text { response }\end{array}$ & $\begin{array}{l}1.87 \mathrm{E}-04 \\
\text { to } 1.24 \mathrm{E} \\
-21\end{array}$ & $\begin{array}{l}\text { Immunological } \\
\text { disease }\end{array}$ & $\begin{array}{l}3.44 \mathrm{E}-03 \\
\text { to } 3.53 \mathrm{E} \\
-10\end{array}$ & $\begin{array}{l}\text { Neurological } \\
\text { disease }\end{array}$ & $\begin{array}{l}2.91 \mathrm{E}-04 \\
\text { to } 6.16 \mathrm{E} \\
-15\end{array}$ & $\begin{array}{l}\text { Inflammatory } \\
\text { response }\end{array}$ & $\begin{array}{l}5.16 \mathrm{E}-04 \\
\text { to } 6.67 \mathrm{E} \\
-16\end{array}$ & $\begin{array}{l}\text { Immunological } \\
\text { disease }\end{array}$ & $\begin{array}{l}1.95 \mathrm{E}-03 \\
\text { to } 2.21 \mathrm{E} \\
-13\end{array}$ \\
\hline $\begin{array}{l}\text { Neurological } \\
\text { disease }\end{array}$ & $\begin{array}{l}2.03 \mathrm{E}-04 \\
\text { to } 1.37 \mathrm{E} \\
-21\end{array}$ & $\begin{array}{l}\text { Inflammatory } \\
\text { disease }\end{array}$ & $\begin{array}{l}2.94 \mathrm{E}-03 \\
\text { to } 3.53 \mathrm{E} \\
-10\end{array}$ & $\begin{array}{l}\text { Psychological } \\
\text { disorders }\end{array}$ & $\begin{array}{l}2.55 \mathrm{E}-04 \\
\text { to } 6.16 \mathrm{E} \\
-15\end{array}$ & $\begin{array}{l}\text { Organismal } \\
\text { injury and } \\
\text { abnormalities }\end{array}$ & $\begin{array}{l}5.16 \mathrm{E}-04 \\
\text { to } 6.67 \mathrm{E} \\
-16\end{array}$ & $\begin{array}{l}\text { Inflammatory } \\
\text { disease }\end{array}$ & $\begin{array}{l}2.55 \mathrm{E}-03 \\
\text { to } 2.21 \mathrm{E} \\
-13\end{array}$ \\
\hline
\end{tabular}


Table 6 Top diseases and bio functions-physiological system development and function

\begin{tabular}{|c|c|c|c|c|c|c|c|c|c|}
\hline Patient 1 & & Patient 2 & & Patient 3 & & Patient 4 & & Patient 5 & \\
\hline Protein & $P$ value & Protein & $P$ value & Protein & $P$ value & Protein & $P$ value & Protein & $P$ value \\
\hline $\begin{array}{l}\text { Immune cell } \\
\text { trafficking }\end{array}$ & $\begin{array}{l}1.23 \mathrm{E} \\
-04 \text { to } \\
3.97 \mathrm{E} \\
-15\end{array}$ & $\begin{array}{l}\text { Immune cell } \\
\text { trafficking }\end{array}$ & $\begin{array}{l}4.02 \mathrm{E} \\
-03 \text { to } \\
1.33 \mathrm{E} \\
-08\end{array}$ & $\begin{array}{l}\text { Immune cell } \\
\text { trafficking }\end{array}$ & $\begin{array}{l}3.34 \mathrm{E} \\
-04 \text { to } \\
2.69 \mathrm{E} \\
-16\end{array}$ & $\begin{array}{l}\text { Immune cell } \\
\text { trafficking }\end{array}$ & $\begin{array}{l}5.24 \mathrm{E} \\
-04 \text { to } \\
2.61 \mathrm{E} \\
-13\end{array}$ & $\begin{array}{l}\text { Immune cell } \\
\text { trafficking }\end{array}$ & $\begin{array}{l}2.48 \mathrm{E} \\
-03 \text { to } \\
2.24 \mathrm{E} \\
-11\end{array}$ \\
\hline $\begin{array}{l}\text { Hematological } \\
\text { system } \\
\text { development and } \\
\text { function }\end{array}$ & $\begin{array}{l}2.01 \mathrm{E} \\
-04 \text { to } \\
1.33 \mathrm{E} \\
-13\end{array}$ & $\begin{array}{l}\text { Hematological } \\
\text { system } \\
\text { development and } \\
\text { function }\end{array}$ & $\begin{array}{l}4.02 \mathrm{E} \\
-03 \text { to } \\
5.37 \mathrm{E} \\
-07\end{array}$ & $\begin{array}{l}\text { Hematological } \\
\text { system } \\
\text { development and } \\
\text { function }\end{array}$ & $\begin{array}{l}3.34 \mathrm{E} \\
-04 \text { to } \\
1.79 \mathrm{E} \\
-12\end{array}$ & $\begin{array}{l}\text { Hematological } \\
\text { system } \\
\text { development and } \\
\text { function }\end{array}$ & $\begin{array}{l}5.24 \mathrm{E} \\
-04 \text { to } \\
4.87 \mathrm{E} \\
-12\end{array}$ & $\begin{array}{l}\text { Hematological } \\
\text { system } \\
\text { development and } \\
\text { function }\end{array}$ & $\begin{array}{l}2.55 \mathrm{E} \\
-03 \text { to } \\
1.31 \mathrm{E} \\
-09\end{array}$ \\
\hline $\begin{array}{l}\text { Cardiovascular } \\
\text { system } \\
\text { development and } \\
\text { function }\end{array}$ & $\begin{array}{l}1.66 \mathrm{E} \\
-04 \text { to } \\
1.20 \mathrm{E} \\
-11\end{array}$ & $\begin{array}{l}\text { Humoral immune } \\
\text { response }\end{array}$ & $\begin{array}{l}2.42 \mathrm{E} \\
-03 \text { to } \\
2.83 \mathrm{E} \\
-06\end{array}$ & $\begin{array}{l}\text { Tissue } \\
\text { morphology }\end{array}$ & $\begin{array}{l}3.21 \mathrm{E} \\
-04 \text { to } \\
5.10 \mathrm{E} \\
-10\end{array}$ & $\begin{array}{l}\text { Cardiovascular } \\
\text { system } \\
\text { development and } \\
\text { function }\end{array}$ & $\begin{array}{l}5.24 \mathrm{E} \\
-04 \text { to } \\
1.56 \mathrm{E} \\
-10\end{array}$ & $\begin{array}{l}\text { Organismal } \\
\text { development }\end{array}$ & $\begin{array}{l}1.88 \mathrm{E} \\
-03 \text { to } \\
2.65 \mathrm{E} \\
-07\end{array}$ \\
\hline $\begin{array}{l}\text { Organismal } \\
\text { development }\end{array}$ & $\begin{array}{l}1.66 \mathrm{E} \\
-04 \text { to } \\
5.69 \mathrm{E} \\
-11\end{array}$ & $\begin{array}{l}\text { Organismal } \\
\text { development }\end{array}$ & $\begin{array}{l}4.02 \mathrm{E} \\
-03 \text { to } \\
3.65 \mathrm{E} \\
-05\end{array}$ & $\begin{array}{l}\text { Organismal } \\
\text { development }\end{array}$ & $\begin{array}{l}2.62 \mathrm{E} \\
-04 \text { to } \\
5.04 \mathrm{E} \\
-09\end{array}$ & $\begin{array}{l}\text { Organismal } \\
\text { development }\end{array}$ & $\begin{array}{l}4.95 \mathrm{E} \\
-04 \text { to } \\
2.22 \mathrm{E} \\
-10\end{array}$ & $\begin{array}{l}\text { Humoral immune } \\
\text { response }\end{array}$ & $\begin{array}{l}9.19 \mathrm{E} \\
-04 \text { to } \\
2.78 \mathrm{E} \\
-07\end{array}$ \\
\hline $\begin{array}{l}\text { Humoral immune } \\
\text { response }\end{array}$ & $\begin{array}{l}6.88 \mathrm{E} \\
-05 \text { to } \\
2.84 \mathrm{E} \\
-10\end{array}$ & $\begin{array}{l}\text { Lymphoid tissue } \\
\text { structure and } \\
\text { development }\end{array}$ & $\begin{array}{l}3.90 \mathrm{E} \\
-03 \text { to } \\
4.99 \mathrm{E} \\
-05\end{array}$ & $\begin{array}{l}\text { Organismal } \\
\text { survival }\end{array}$ & $\begin{array}{l}3.81 \mathrm{E} \\
-06 \text { to } \\
8.49 \mathrm{E} \\
-09\end{array}$ & $\begin{array}{l}\text { Organismal } \\
\text { survival }\end{array}$ & $\begin{array}{l}1.89 \mathrm{E} \\
-05 \text { to } \\
1.27 \mathrm{E} \\
-08\end{array}$ & $\begin{array}{l}\text { Tissue } \\
\text { morphology }\end{array}$ & $\begin{array}{l}2.27 \mathrm{E} \\
-03 \text { to } \\
4.15 \mathrm{E}- \\
07\end{array}$ \\
\hline
\end{tabular}

associated LXR/RXR was among the top canonical pathways affected. Further studies are necessary to determine whether APOBEC3A, SERPINA3, and ORM2 are potential AAU biomarkers.

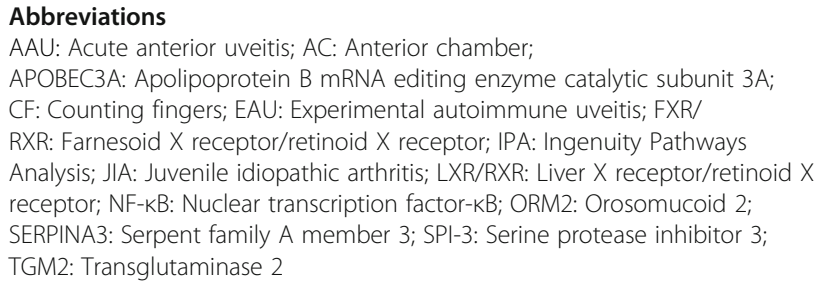

\section{Acknowledgements}

Not applicable.

\section{Authors' contributions}

JRE examined the patients and collected the tear samples. MP analyzed the tear samples with proteomics. JRE, IGF, and OKO performed IPA. All authors participated in the critical revision and correction of the manuscript. All authors read and approved the final manuscript.

\section{Funding}

The study was funded by The Norwegian Association of the Blind and Partially Sighted, The Olav Raagholt and Gerd Meidel Raagholt Research Foundation, and Arthur og Odd Clausons Legat.

\section{Availability of data and materials}

Not applicable.

\section{Ethics approval and consent to participate}

The study (project number 2017/345) was approved by the Regional Committees for Medical and Health Research Ethics in Norway and adhered to the tenets of the Declaration of Helsinki. Written informed consent was obtained from all subjects.

\section{Consent for publication}

Written informed consent was obtained from all subjects.

\section{Competing interests}

The authors report no competing interests.

\section{Author details}

${ }^{1}$ Center for Eye Research, Department of Ophthalmology, Oslo University Hospital, University of Oslo, Oslo, Norway. ${ }^{2}$ Faculty of Dentistry, Department of Oral Biology, University of Oslo, Oslo, Norway. ${ }^{3}$ Blood Cell Research Group, Section for Research, Department of Medical Biochemistry, Oslo University Hospital, Oslo, Norway. ${ }^{4}$ Hormone Laboratory, Department of Medical Biochemistry, Oslo University Hospital, Oslo, Norway.

Received: 5 September 2019 Accepted: 3 May 2020

Published online: 27 May 2020

\section{References}

1. Zierhut M, Pavesio CE, Goldstein DA (2016) Anterior uveitis. In: Zierhut M, Pavesio CE, Ohno S, Orefice F, Rao N (eds) Intraocular inflammation: Springer. Heidelberg, Berlin, pp 503-516

2. Agrawal RV, Murthy S, Sangwan V, Biswas J. Current approach in diagnosis and management of anterior uveitis. Indian J Ophthalmol. 2010;58(1):11-9. doi: 10.4103/0301-4738.58468. PubMed PMID: 20029142; PubMed Central PMCID: PMCPMC2841369.

3. Carreno E, Portero A, Herreras JM, Garcia-Vazquez C, Whitcup SM, Stern ME, et al. Cytokine and chemokine tear levels in patients with uveitis. Acta Ophthalmol. 2016. doi: https://doi.org/10.1111/aos.13292. PubMed PMID: 27873479

4. Aass C, Norheim I, Eriksen EF, Thorsby PM, Pepaj M. Single unit filter-aided method for fast proteomic analysis of tear fluid. Anal Biochem 2015;480:1-5. Epub 2015/04/12. doi: https://doi.org/10.1016/j.ab.2015.04.002. PubMed PMID: 25862084

5. Aass C, Norheim I, Eriksen EF, Bornick EC, Thorsby PM, Pepaj M. Comparative proteomic analysis of tear fluid in Graves' disease with and without orbitopathy. Clin Endocrinol 2016;85(5):805-812. doi: https://doi.org/10.1111/ cen.13122. PubMed PMID: 27256639.

6. Angeles-Han S, Duong D, Yeh S, Patel P, Jenkins K, Prahalad S, et al. dentification of biomarkers using tear proteomics in children with chronic anterior uveitis. 2016 ACR/ARHP Annual Meeting2016.

7. Chasnyk VG, Gaidar EV, Kononov AV, Ammosova T, Hynes A, Dubko MF, et al. Proteomic profile of tears for the diagnosis of uveitis associated with juvenile idiopathic arthritis: setting targets to achieve results. Pediatrician (St Petersburg). 2017;8(1):5-26. doi: 10.17816/ped815-26. 
8. Bioinformatics \& Evolutionary Genomics [June 7, 2019]. Available from: http://bioinformatics.psb.ugent.be/webtools/Nenn/.

9. Zelcer $\mathrm{N}$, Tontonoz P. Liver $\mathrm{X}$ receptors as integrators of metabolic and inflammatory signaling. J Clin Invest. 2006;116(3):607-14. Epub 2006/03/03. doi: 10.1172/JCI27883. PubMed PMID: 16511593; PubMed Central PMCID: PMCPMC1386115.

10. Joseph SB, Castrillo A, Laffitte BA, Mangelsdorf DJ, Tontonoz P. Reciprocal regulation of inflammation and lipid metabolism by liver $X$ receptors. Nat Med 2003;9(2):213-219. Epub 2003/01/14. doi: https://doi.org/10.1038/ nm820. PubMed PMID: 12524534.

11. Castrillo A, Joseph SB, Marathe C, Mangelsdorf DJ, Tontonoz P. Liver X receptor-dependent repression of matrix metalloproteinase- 9 expression in macrophages. J Biol Chem 2003;278(12):10443-10449. doi: https://doi.org/10. 1074/jbc.M213071200. PubMed PMID: 12531895

12. Fang IM, Yang CH, Lin CP, Yang CM, Chen MS. Effects of pyrrolidine dithiocarbamate, an NF-kappaB inhibitor, on cytokine expression and ocular inflammation in experimental autoimmune anterior uveitis. J Ocul Pharmacol Ther 2005;21(2):95-106. doi: https://doi.org/10.1089/jop.2005.21. 95. PubMed PMID: 15857275

13. Yang $H$, Zheng $S$, Qiu $Y$, Yang $Y$, Wang $C$, Yang $P$, et al. Activation of liver $X$ receptor alleviates ocular inflammation in experimental autoimmune uveitis. Invest Ophthalmol Vis Sci. 2014;55(4):2795-804. doi: 10.1167/iovs.13-13323. PubMed PMID: 24699378; PubMed Central PMCID: PMCPMC4004425.

14. Mukwaya A, Lennikov A, Xeroudaki M, Mirabelli P, Lachota M, Jensen L, et al. Time-dependent LXR/RXR pathway modulation characterizes capillary remodeling in inflammatory corneal neovascularization. Angiogenesis. 2018; 21(2):395-413. Epub 2018/02/16. doi: 10.1007/s10456-018-9604-y. PubMed PMID: 29445990; PubMed Central PMCID: PMCPMC5878196.

15. Kalariya NM, Shoeb M, Reddy AB, Zhang M, van Kuijk FJ, Ramana KV Prevention of endotoxin-induced uveitis in rats by plant sterol guggulsterone. Invest Ophthalmol Vis Sci. 2010;51(10):5105-13. doi: 10.1167/ iovs.09-4873. PubMed PMID: 20435582; PubMed Central PMCID: PMCPMC2946978.

16. de Vos AF, Klaren VN, Kijlstra A. Expression of multiple cytokines and IL-1RA in the uvea and retina during endotoxin-induced uveitis in the rat. Invest Ophthalmol Vis Sci 1994;35(11):3873-3883. Epub 1994/10/01. PubMed PMID: 7928184.

17. Nakamura S, Yamakawa T, Sugita M, Kijima M, Ishioka M, Tanaka S, et al. The role of tumor necrosis factor-alpha in the induction of experimental autoimmune uveoretinitis in mice. Invest Ophthalmol Vis Sci 1994;35(11): 3884-3889. Epub 1994/10/01. PubMed PMID: 7928185.

18. Santos Lacomba M, Marcos Martin C, Gallardo Galera JM, Gomez Vidal MA, Collantes Estevez E, Ramirez Chamond R, et al. Aqueous humor and serum tumor necrosis factor-alpha in clinical uveitis. Ophthalmic Res 2001;33(5): 251-255. Epub 2001/10/05. doi: https://doi.org/10.1159/000055677. PubMed PMID: 11586057.

19. Jaffe GJ, Dick AD, Brezin AP, Nguyen QD, Thorne JE, Kestelyn P, et al. Adalimumab in patients with active noninfectious uveitis. N Engl J Med 2016;375(10):932-943. Epub 2016/09/08. doi: https://doi.org/10.1056/ NEJMoa1509852. PubMed PMID: 27602665.

20. Nguyen QD, Merrill PT, Jaffe GJ, Dick AD, Kurup SK, Sheppard J, et al. Adalimumab for prevention of uveitic flare in patients with inactive noninfectious uveitis controlled by corticosteroids (VISUAL II): a multicentre, double-masked, randomised, placebo-controlled phase 3 trial. Lancet. 2016; 388(10050):1183-1192. Epub 2016/08/21. doi: https://doi.org/10.1016/S01406736(16)31339-3. PubMed PMID: 27542302.

21. Kimura A, Kishimoto T. IL-6: regulator of Treg/Th17 balance. Eur J Immunol 2010;40(7):1830-1835. Epub 2010/06/29. doi: https://doi.org/10.1002/eji. 201040391. PubMed PMID: 20583029

22. Abu El-Asrar AM, Berghmans N, Al-Obeidan SA, Mousa A, Opdenakker G Van Damme J, et al. The cytokine interleukin- 6 and the chemokines CCL2O and CXCL13 are novel biomarkers of specific endogenous uveitic entities. Invest Ophthalmol Vis Sci 2016;57(11):4606-4613. Epub 2016/09/08. doi: https://doi.org/10.1167/iovs.16-19758. PubMed PMID: 27603722

23. Horai R, Caspi RR. Cytokines in autoimmune uveitis. J Interferon Cytokine Res. 2011;31(10):733-44. doi: 10.1089/jir.2011.0042. PubMed PMID: 21787221; PubMed Central PMCID: PMCPMC3189550.

24. Stenglein MD, Burns MB, Li M, Lengyel J, Harris RS. APOBEC3 proteins mediate the clearance of foreign DNA from human cells. Nat Struct Mol Biol. 2010;17(2):222-9. doi: 10.1038/nsmb.1744. PubMed PMID: 20062055; PubMed Central PMCID. PMCPMC2921484
25. Sohn J, Chae JB, Lee SY, Kim SY, Kim JG. A novel therapeutic target in inflammatory uveitis: transglutaminase 2 inhibitor. Korean J Ophthalmol. 2010;24(1):29-34. doi: 10.3341/kjo.2010.24.1.29. PubMed PMID: 20157411; PubMed Central PMCID: PMCPMC2817820.

26. D'Argenio G, Biancone L, Cosenza V, Della Valle N, D'Armiento FP, Boirivant M, et al. Transglutaminases in Crohn's disease. Gut. 1995;37(5):690-5. PubMed PMID: 8549947; PubMed Central PMCID: PMCPMC1382876.

27. Perumal N, Manicam C, Steinicke M, Funke S, Pfeiffer N, Grus FH. Characterization of the human aqueous humour proteome: a comparison of the genders. PLoS One. 2017;12(3):e0172481. doi: 10.1371/journal.pone. 0172481. PubMed PMID: 28273097: PubMed Central PMCID: PMCPMC5342205.

28. Takamiya A, Takeda M, Yoshida A, Kiyama H. Expression of serine protease inhibitor 3 in ocular tissues in endotoxin-induced uveitis in rat. Invest Ophthalmol Vis Sci 2001:42(11):2427-2433. PubMed PMID: 11581179.

29. Gupta AK, Sarin GS, Rastogi A, Grover AK, Pandey PK. Serum alpha-1 acid glycoprotein levels in acute idiopathic anterior uveitis. Ann Ophthalmol 1991:23(11):406-409. PubMed PMID: 1776767.

\section{Publisher's Note}

Springer Nature remains neutral with regard to jurisdictional claims in published maps and institutional affiliations.

\section{Submit your manuscript to a SpringerOpen ${ }^{\circ}$ journal and benefit from:}

- Convenient online submission

- Rigorous peer review

- Open access: articles freely available online

High visibility within the field

- Retaining the copyright to your article

Submit your next manuscript at $\boldsymbol{\nabla}$ springeropen.com 